\title{
Menhaden Oil
}

National Cancer Institute

\section{Source}

National Cancer Institute. Menhaden Oil. NCI Thesaurus. Code C107330.

The oil extracted from various Brevoortia and Ethmidium species. Menhaden oil is used industrially in paint production and the tanning of leather as was as in livestock feeds. 